Natural Hazards and Earth System Sciences (2003) 3: 443-455

(C) European Geosciences Union 2003

Natural Hazards and Earth System Sciences

\title{
Large scale debris-flow hazard assessment: a geotechnical approach and GIS modelling
}

\author{
G. Delmonaco ${ }^{1}$, G. Leoni ${ }^{1}$, C. Margottini ${ }^{1}$, C. Puglisi ${ }^{1}$, and D. Spizzichino ${ }^{2}$ \\ ${ }^{1}$ ENEA CR Casaccia, Via Anguillarese 301, 00060 Rome, Italy \\ ${ }^{2}$ Consorzio Civita, Via del Corso 300, 00168 Rome, Italy
}

Received: 22 July 2002 - Revised: 6 February 2003 - Accepted: 18 February 2003

\begin{abstract}
A deterministic distributed model has been developed for large-scale debris-flow hazard analysis in the basin of River Vezza (Tuscany Region - Italy). This area $\left(51.6 \mathrm{~km}^{2}\right)$ was affected by over 250 landslides. These were classified as debris/earth flow mainly involving the metamorphic geological formations outcropping in the area, triggered by the pluviometric event of 19 June 1996. In the last decades landslide hazard and risk analysis have been favoured by the development of GIS techniques permitting the generalisation, synthesis and modelling of stability conditions on a large scale investigation $(>1: 10000)$. In this work, the main results derived by the application of a geotechnical model coupled with a hydrological model for the assessment of debris flows hazard analysis, are reported. This analysis has been developed starting by the following steps: landslide inventory map derived by aerial photo interpretation, direct field survey, generation of a data-base and digital maps, elaboration of a DTM and derived themes (i.e. slope angle map), definition of a superficial soil thickness map, geotechnical soil characterisation through implementation of a backanalysis on test slopes, laboratory test analysis, inference of the influence of precipitation, for distinct return times, on ponding time and pore pressure generation, implementation of a slope stability model (infinite slope model) and generalisation of the safety factor for estimated rainfall events with different return times.
\end{abstract}

Such an approach has allowed the identification of potential source areas of debris flow triggering. This is used to detected precipitation events with estimated return time of 10 , 50, 75 and 100 years. The model shows a dramatic decrease of safety conditions for the simulation when is related to a 75 years return time rainfall event. It corresponds to an estimated cumulated daily intensity of $280-330 \mathrm{~mm}$. This value can be considered the hydrological triggering threshold for the whole Vezza basin.

Correspondence to: C. Margottini

(margottini@casaccia.enea.it)

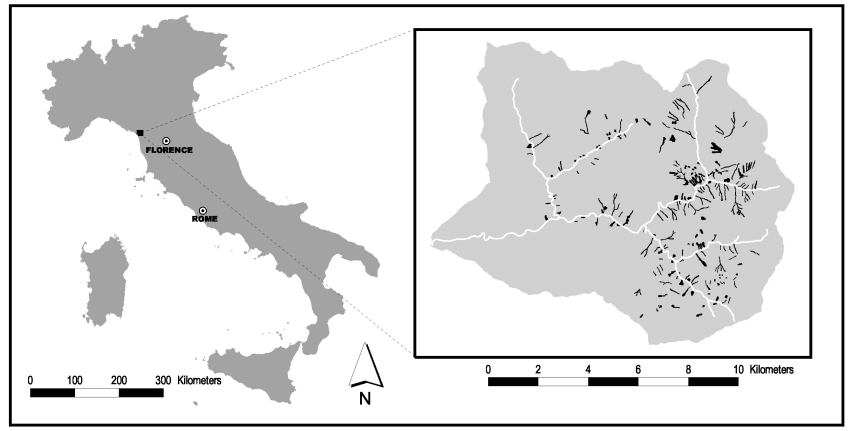

Fig. 1. Location of the River Vezza basin (NW Tuscany). Black dots refer to landslide inventored after the disaster of 19 June 1996; white lines indicate the main river network.

\section{Introduction}

The River Vezza basin is located in the north-western sector of Tuscany in the Apuan Alps with a total catchment area of $51.6 \mathrm{~km}^{2}$ (Fig. 1). It experienced on 19 June 1996 a severe rainstorm event in terms of intensity and cumulated rainfall. The rainfall started at 6:30 am and terminated at $19: 00 \mathrm{pm}$ $478 \mathrm{~mm}$ of cumulated precipitation were recorded at Pomezzana corresponding to approx. $33 \%$ of long-term yearly average rainfall, with $158 \mathrm{~mm} / \mathrm{h}$ as a maximum intensity (Table 1). The analysis of 3, 6, 12, 24 hours of rainfall heights referring to historical records provides return time values from 200 to 500 years (Burlando and Rosso, 1998). The rainstorm was promoted by the peculiarity of the micro-climate of Apuan Alps; this develops from the ascending and rapid cooling of Atlantic wet fronts over the Versilian chain (orographic effect), that resulted in a sudden and concentrated rainfall, in particular during the summer season.

This event caused disruptive and differentiated effects in the mountain and flood plane. A flash-flood destroyed the village of Cardoso causing 14 victims. Most of the road network was interrupted and disrupted while some hundred 
Table 1. Rainfall records for Retignano and Pomezzana (19 Jun 1996)(Rapetti and Rapetti, 1996)

\begin{tabular}{lccccccccc}
\hline Stations & $\begin{array}{c}\text { Height } \\
(\mathrm{m})\end{array}$ & $\begin{array}{c}\text { Tot.Prec } \\
(\mathrm{mm})\end{array}$ & $\begin{array}{c}\text { Max. Int. } \\
(\mathrm{mm} / \mathrm{h})\end{array}$ & $\begin{array}{c}\text { Max. Int. } \\
(\mathrm{mm} / 5 \mathrm{~min})\end{array}$ & Hour & $\begin{array}{c}\text { Av. Int. } \\
(\mathrm{mm} / \mathrm{h})\end{array}$ & $\begin{array}{c}\text { Event } \\
\text { starting }\end{array}$ & $\begin{array}{c}\text { Event } \\
\text { ending }\end{array}$ & $\begin{array}{c}\text { Dur. } \\
(\mathrm{h})\end{array}$ \\
\hline Retignano & 325 & 400,6 & 62,6 & 13,2 & $7: 10$ & 26,7 & 4.10 & 19.10 & 15.00 \\
Pomezzana & 597 & 477,4 & 158 & 30,8 & $6: 30$ & 30,8 & 3.50 & 19.20 & 15.30 \\
\hline
\end{tabular}

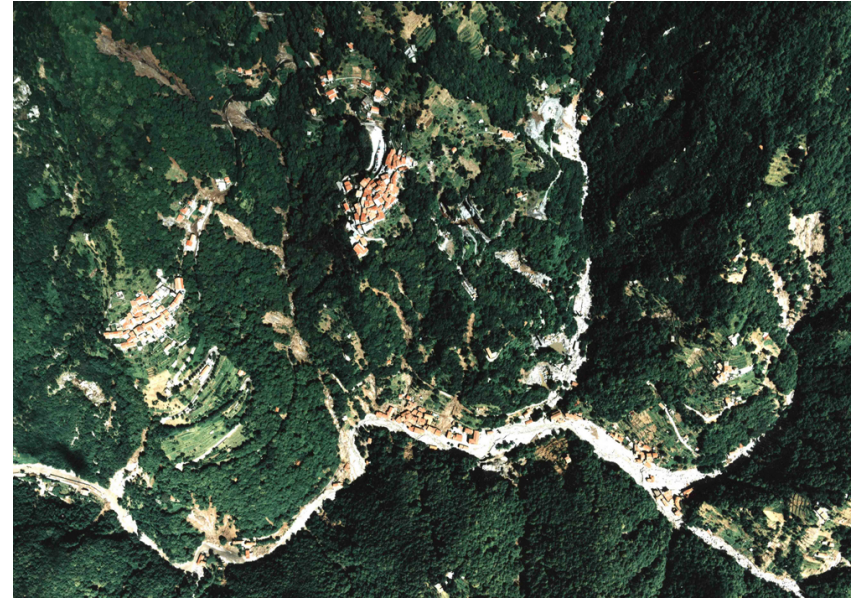

Fig. 2. Aerial photo of NE sector of River Vezza basin. This portion of the basin (approx. $2.5 \mathrm{~km}^{2}$ ) evidenced the highest landslide density ( $>20$ landslide $/ \mathrm{km}^{2}$ and $10 \%$ of the area affected) and damage caused by the rainstorm of 19 June 1996. The village of Cardoso, sited in the confluence of two torrents, is visible on the right bottom of the photo; The territories of Pruno (right side) and Volegno (center) have been heavily affected by landsliding.

landslides (mostly debris flows) were triggered along the slopes (Figs. 2 and 3).

Rapid infiltration of rainfall and the increasing of pore pressures can be considered the main trigger of debris/earth flows generation (Campbell, 1974; Wieczoreck, 1987, 1996). Historical analysis has stressed that the study area is highly prone to simultaneous triggering of superficial landsliding and flooding associated with intense precipitation. Large floods occurred in 1774, 1885, 1902 while minor events have a 25-30 years return time. The flood of 25 September 1885 (Figs. 4 and 5) seems to be comparable with the 1996 disaster in terms of magnitude and associated damage (Martini and Paolini, 2000).

The analysis of the 19 June 1996 disaster as well as historical occurrences of landslides, emphasizes that heavy rainfall promotes a generalised instability of the Vezza basin. This area is highly susceptible to superficial landsliding that involves mainly the soil cover of slopes. Such condition suggests the necessity to undertake a spatial analysis for landslide hazard assessment of the area using the potentiality of a GIS. The adoption of a GIS actually allows the analysis,

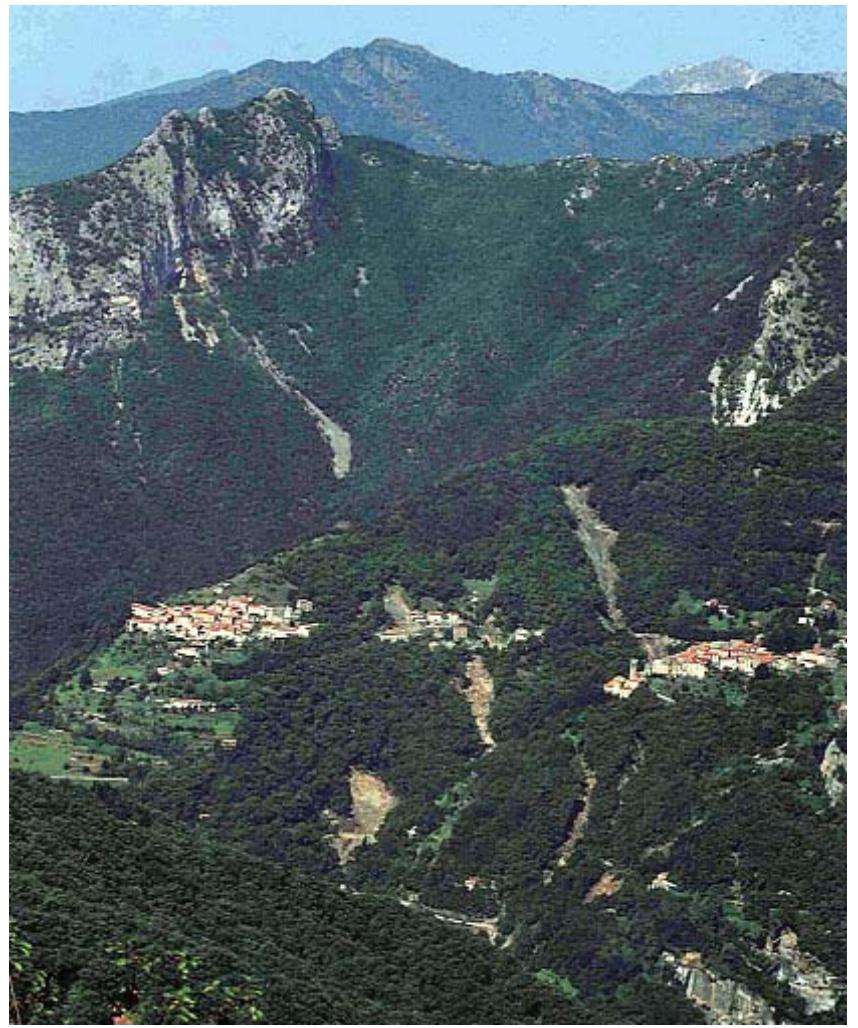

Fig. 3. Front view of NE sector of River Vezza basin. Debris flows/slides developed along slopes are clearly visible. The villages of Pruno (right side) and Volegno (left side) were partially affected or menaced by landslides.

modelling and spatialising slope stability conditions through a physically-based approach, using rather simple geotechnical models.

In literature many techniques and methodologies on landslide hazard assessment have been proposed with respect to various approaches. A review on such methods has been recently developed by Hutchinson (1995), Aleotti and Chowdhury (1999), and Guzzetti et al. (1999).

Deterministic approaches are based on slope stability analysis (safety factor analysis) and are generally assessed through the definition of main physical parameters of terrains and application of static models, using the infinite slope model. Here the equilibrium of forces along a potential failure surface is considered (Skempton and DeLory, 1957). De- 


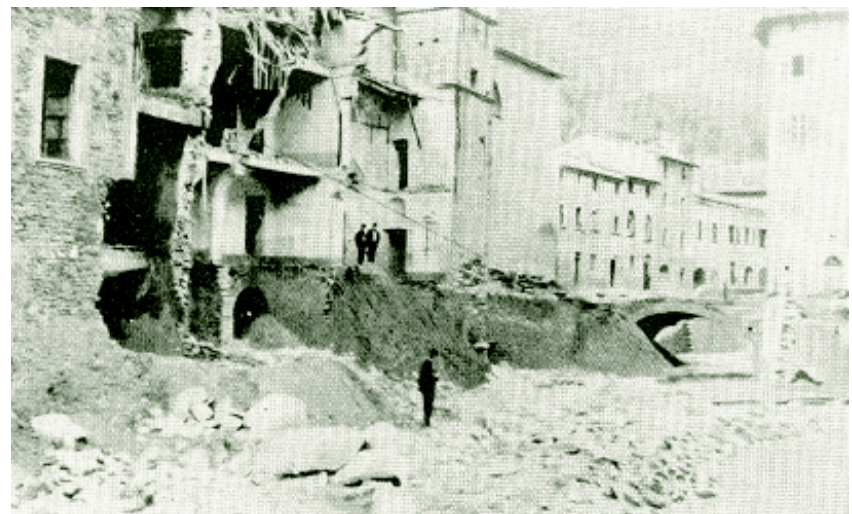

Fig. 4. Image of Seravezza, sited at the final section of the Vezza River. The photo shows the effects of the flooding occurred on 25 September 1885.

terministic distributed modelling may be potentially applied in areas susceptible to shallow landslides where an instability mechanism is generally ruled by critical values of heavy rainfall. This generates a rapid and diffused instability of superficial soil cover. Under such conditions, a landslide hazard analysis of large areas can be successful through relatively simple approaches by coupling an infiltration model of rainfall with a slope stability model (van Westen, 1993, 1994; Montgomery et al., 1994; Terlien et al., 1995; Dietrich et al., 1997).

The aim of this work is to apply a distributed deterministic model for assessing stability conditions of hillslopes of the River Vezza Basin.

\section{Geological and geomorphological setting}

The catchment area of the Vezza river is characterised by a high slope gradient with deep valleys and steep slopes with average of $30^{\circ}-35^{\circ}$ and peaks of $60^{\circ}$ (Fig. 6). This mainly concentrates at the Apuan watershed. The hydrographical network shows a typically low evolution, with few main channels and many tributaries, with linear pattern and slopes $>20^{\circ}\left(30^{\circ}-40^{\circ}\right.$ along the watershed).

The bedrock is mainly formed by meta-sedimentary terrain belonging to the Apuan Metamorphic Complex; this bedrock outcrops over $75 \%$ of the area and, subordinately, by limestone and dolomite. All terrain develops a soil cover especially at medium/low heights, as the result of weathering. The depth of colluvium is mainly $1.0-3.0 \mathrm{~m}$. The map of the bedrock is shown in Fig. 7.

Regarding land use, approximately $80 \%$ of hillslopes are covered by forests (chestnut, coniferous and oaks) while high slopes are covered by bushes or grass. The calcareous bedrock outcrops on the steepest areas with gradients $>45^{\circ}$.

The mean rainfall climate presents high annual rainfall rates (up to almost $2000 \mathrm{~mm}$ per year). The precipitation pattern is generally characterised by extreme events that may

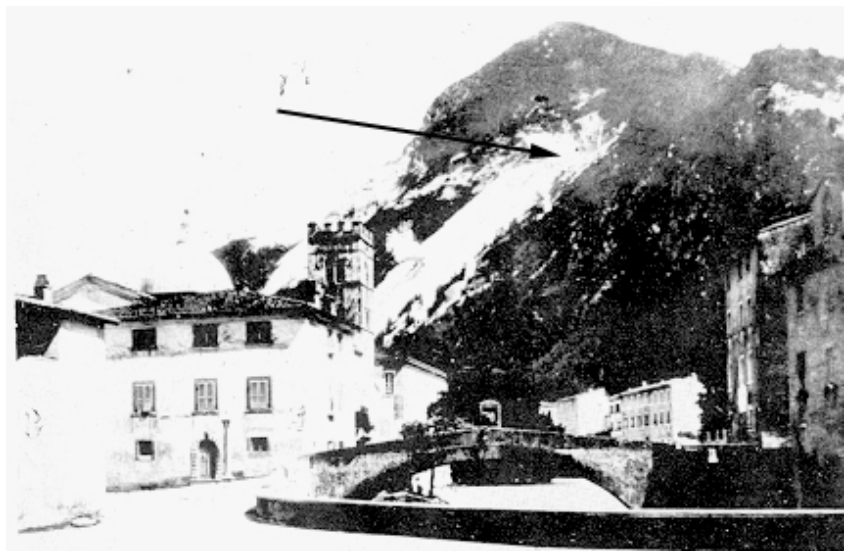

Fig. 5. Flooding of 25 September 1885 at Seravezza. The arrow indicates a large landslide area, probably a debris slide, occurred during the meteorological event.

result in a daily intensity of $300 \mathrm{~mm}$. Rainfall generally increases with time and the height of the slopes (Rapetti and Rapetti, 1996).

Topographical features have been derived from the generation of a Digital Elevation Model (cell size $5 \mathrm{~m}$ ). The map, realised with ArcView $\backslash$ huhESRI, has been derived by a TIN (Triangular Irregular Network) model (Fig. 6).

\section{Landslide typologies and kinematics}

The effects of the 19 June 1996 event can be recognised mainly by two distinct phenomena strictly connected: superficial landslides and hyperconcentrated flow of solid loads along rivers. Subordinately few deep-sited landslides have been re-activated by the event (Codebò et al., 2000).

A field survey undertaken immediately after the disaster has permitted the making of an inventory of landslides, reconstruction of typologies, geomorphological parameters and kinematics of movements. The debris/earth flows occurred mainly along first order channels and main rivers. Here the concave morphology in the interface bedrockcoverage promotes the concentration of water seepage, saturation and increase of pore pressure, up to the failure (Wieczorek, 1987, 1996). Generally, landsliding begins as debrisslide over $30^{\circ}-45^{\circ}$ slopes, along the contact surface between weathered rocks and the bedrock. This occurs mostly in metamorphic terrains (meta-sandstone and phyllites); moreover, the groundwater level base can be identified at the contact of the soil-bedrock. Most landslides that developed along slopes, display a failure depth of $0.5-3.0 \mathrm{~m}$ that correspond to the contact colluvium-bedrock (Fig. 8).

After the initial mobilisation, a rapid failure and displacement occur in a chaotic mixture of coarse and fine materials (from clays to rock blocks) containing a variable amount of water and organic material. The movement evolves along the slope under a quasi-viscous flow (Pierson and Costa, 

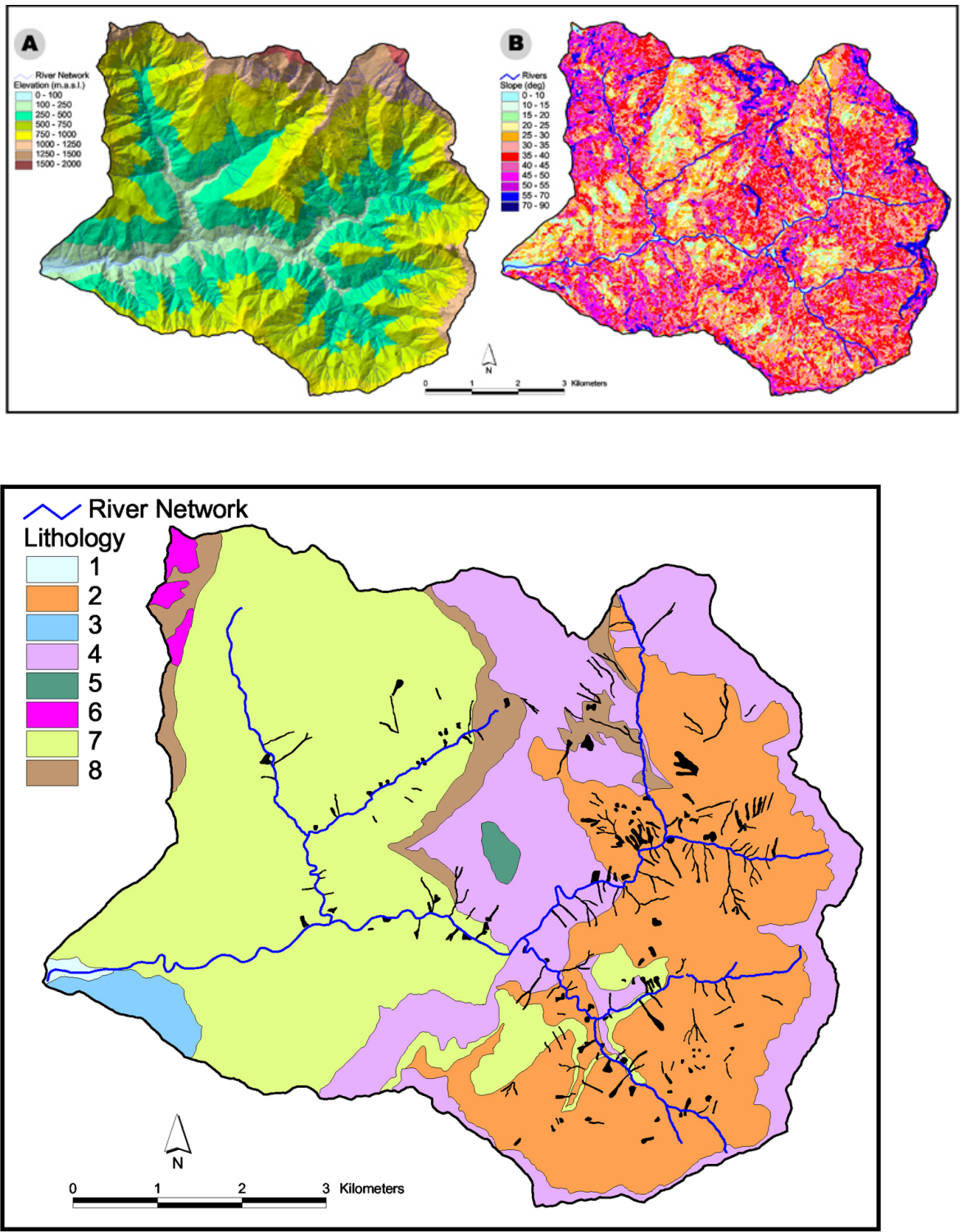

Fig. 6. Morphometric features of River Vezza basin. (a) Digital Elevation Model with cell resolution $5 \mathrm{~m} \times 5 \mathrm{~m}$, derived from digitalisation of topographical maps of Tuscany Region at scale 1:5000. (b) Map of slope angles. The map has been derived automatically from the Digital Elevation Model.

Fig. 7. Lithological map of River Vezza basin: (1) talus and alluvial deposits (Holocene); (2) metamorphic phyllites of Pseudomacigno formation represented by alternance of silty schists and arenaceous schists (Oligocene-Miocene); (3) metamorphic stratified limestone (CretaceousEocene); (4) metamorphic dark grey dolomitic limestone (Jurassic); (5) metamorphic white and grey saccharide limestone (Jurassic); (6) Grezzoni formation formed by dark grey dolomites and grey dolomitic limestone (Trias); (7) metamorphic phyllites of Verrucano formation (Paleozoic-Trias); (8) metamorphic porphiric schists (PaleozoicTrias).

Black areas refer to landslides triggered during 19th June 1996 rainstorm.
1987 ) and generally, with a high velocity (from $10 \mathrm{~cm} / \mathrm{s}$ to some $\mathrm{m} / \mathrm{s}$ ) (Fig. 9). The high velocity determines superficial erosion of the slopes and an increase of sediment transport (debris, soil, vegetation) along the channels (plough effect). This results in a total erosion of the superficial soil cover and vegetation in large forested areas, or in partial transportation of blocks. This can sometimes affect the road network and the houses. On footslopes and along channels, relatively fluid numerous landslide deposits were accumulated. At the highest portion of the slopes, where calcareous rocks outcrop, landsliding has mainly involved coarse materials. especially along rock channels. Further on this provides large blocks with a high potential run-out. These conditions promote accumulation of debris, from water courses to the floodplane, which causes two distinct effects:

(a) hyperconcentrated flow or debris torrent (Pierson and Costa, 1987; Crosta et al., 1990) with high disruptive consequences to human settlements (village of Cardoso, Fig. 10);

(b) overflooding in the lower part of the Vezza basin.

The accumulation of coarse debris, trunks and other materials generates temporary dams. Their collapse triggers pulsing waves with increasing disruptive energy. The high erosion capacity and transport, and hence, flood-wave energy, are testified by rock blocks with volumes $>10 \mathrm{~m}^{3}$ (up to $25 \mathrm{~m}^{3}$ with an estimated weight of 65 tons). The effects of this type of flooding, caused the disruption of several bridges, overflooding (ca. $2 \mathrm{~m}$ ) and promoted the triggering of debrisslides. This developed along the slopes which were generated by toe erosion as well as the re-mobilisation of numerous quarry wastes.

A geomorphological analysis, carried out by the interpretation of aerial photos at scale 1:8000 (together with direct 


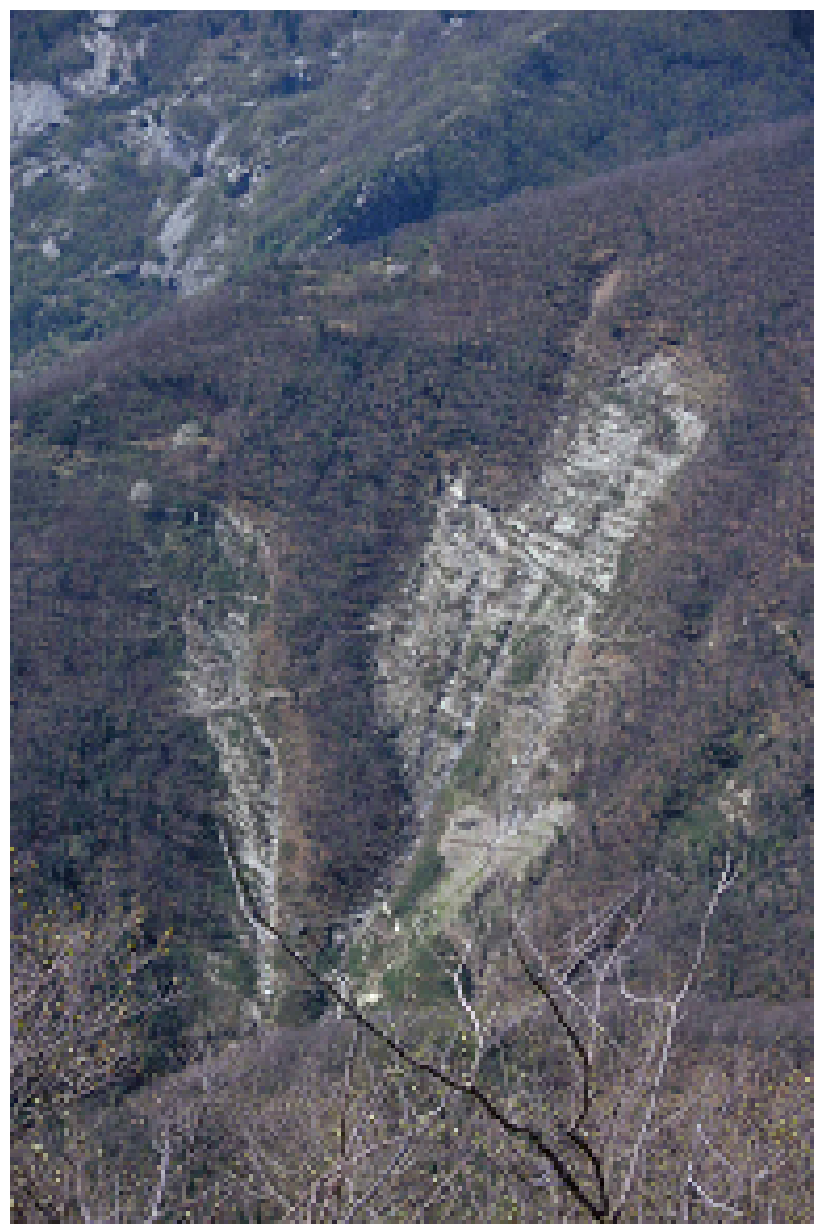

Fig. 8. Debris slide involving the contact colluvium - bedrock.

Table 2. Permeability range of terrains

\begin{tabular}{ll}
\hline Geological formation & Permeability K $(\mathrm{cm} / \mathrm{s})$ \\
\hline Pseudomacigno: & $1 \times 10^{-4}-1 \times 10^{-6}$ \\
Verrucano: & $1 \times 10^{-5}-1 \times 10^{-7}$ \\
Limestone: & $1 \times 10^{-3}-1 \times 10^{-5}$
\end{tabular}

field) detected some hundred first generation superficial landslides, classified as translational slides and rotational slides which evolve in debris-flow or earth-flow (Carrara et al., 1987; Corominas et al., 1996; Cruden and Varnes, 1996). They can develop either along channels, or involving larger portions of the slope (Crosta et al., 1990). The landslide inventory map (Fig. 11), drawn in vector format, details 237 major debris-flows, differentiated into three distinct sectors: source, transport and accumulation areas.

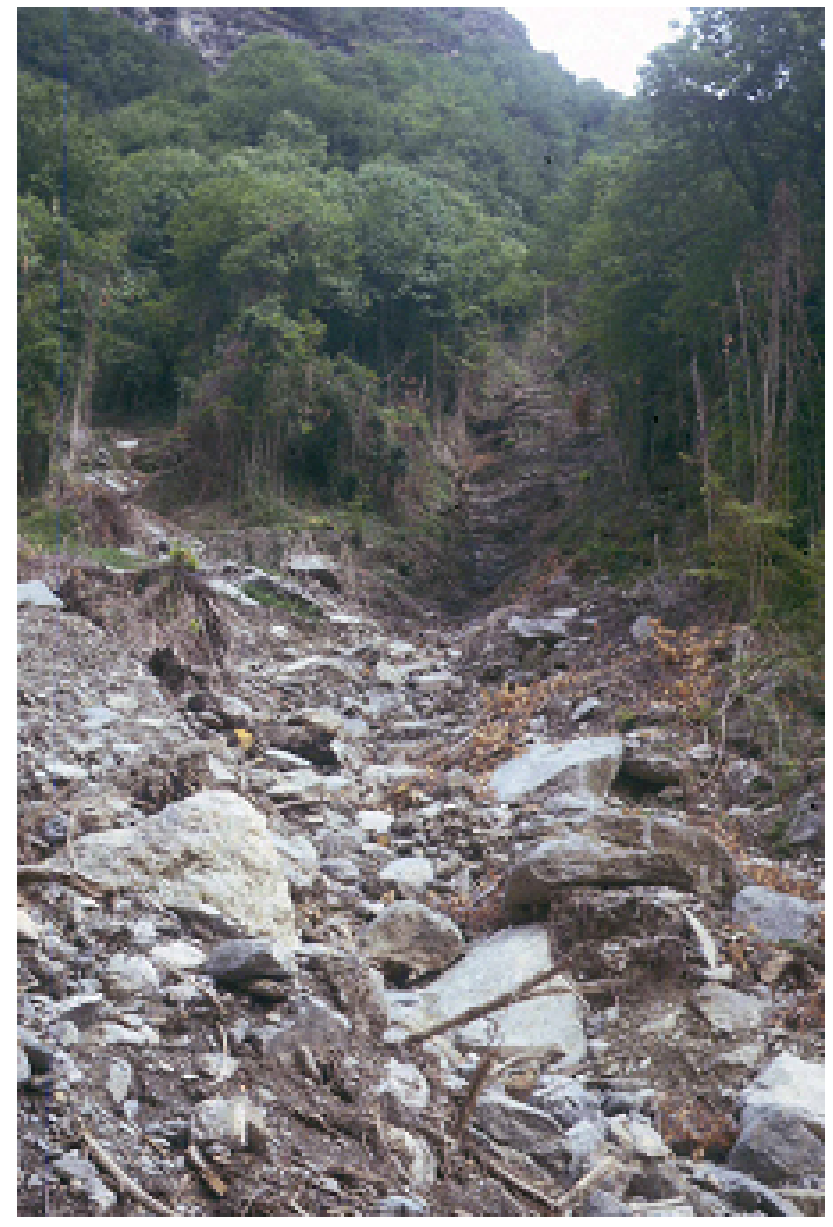

Fig. 9. Linear debris flow evolving along the slope channel.

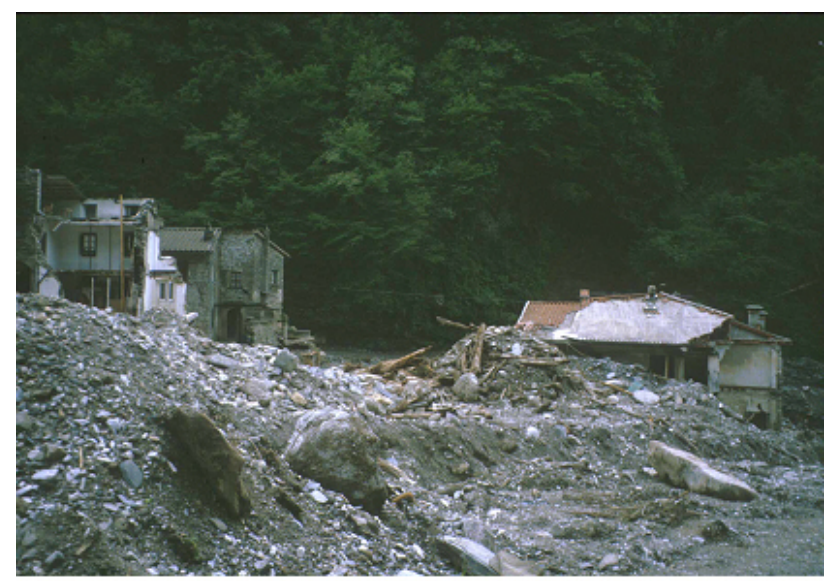

Fig. 10. Debris flow at Cardoso (upper part of River Vezza basin) This event caused 14 victims and destroyed part of the village during the rainstorm of 19 June 1996.

\section{Geotechnical characterisation of terrains}

The geotechnical analysis has mainly focused on the estimation of hydraulic and strength parameters. This is in order to 


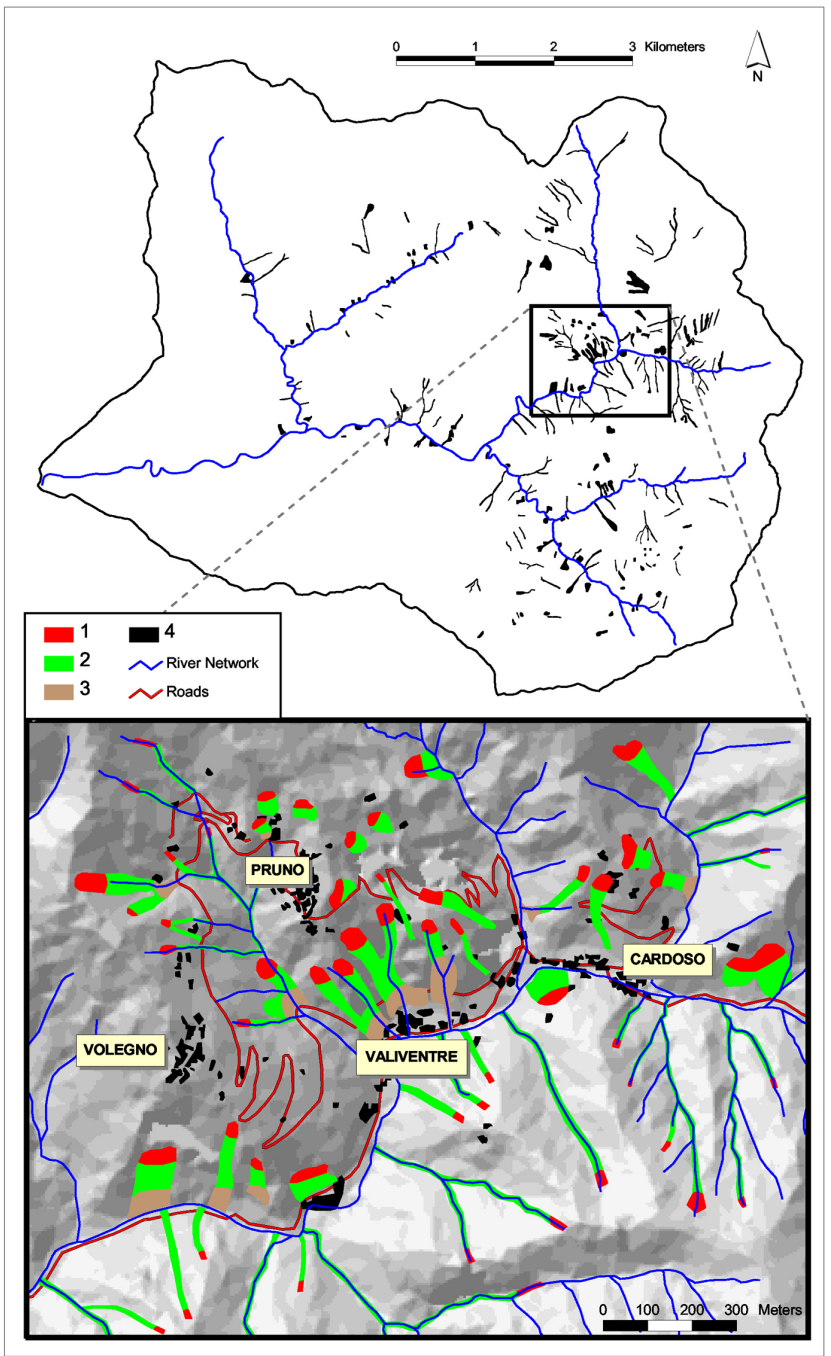

Fig. 11. Inventory map of debris flows triggered in the River Vezza basin during the 19 June 1996 rainstorm. Inventory has been derived from aerial photo analysis and direct field survey. Landslides (black areas in the general map of the basin) have been differentiated in three sectors (detailed area): (1) detachment; (2) track; (3) accumulation. The map shows also location of main urban areas (4), fluvial network and roads.

implement an algorithm for large scale stability analysis with GIS. Hydraulic conductivity of terrains has been estimated from field and laboratory tests, as well as from a data collection of technical and scientific literature. The soils have been sampled at 12 different sites, distributed all over the study area and representative of geological formations involved in slope instability. A grain-size distribution (Fig. 12) has been produced by sifting and an $\mathrm{x}$-ray diffractometric analysis for silt and clay fractions. This has permitted also the detection of the permeability range of terrains (Table 2).

The shear strength parameters of terrains have been assessed through a back-analysis using the Limit Equilibrium method and, in particular, the Infinite Slope method (Skempton and DeLory, 1957). The assumption of the infinite slope

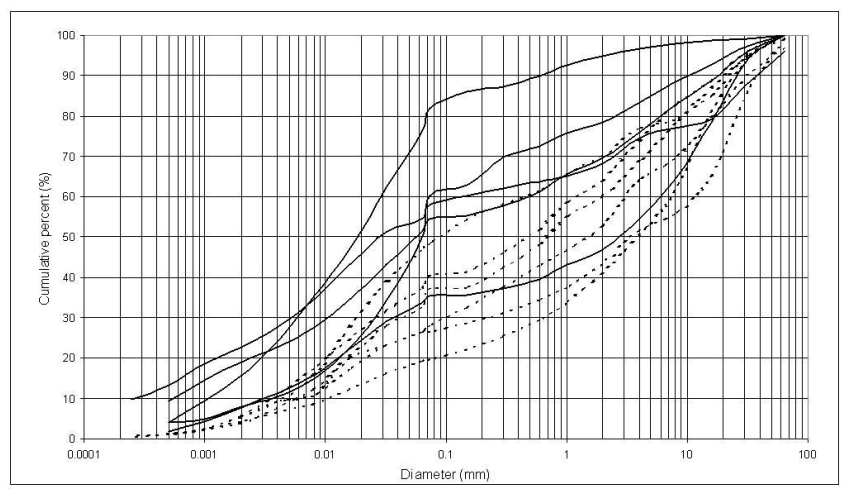

Fig. 12. Grain-size distribution of Pseudomacigno (continuous line) and Verrucano samples (dashed line) obtained through sifting and $\mathrm{x}$-ray diffrattometric analyses.

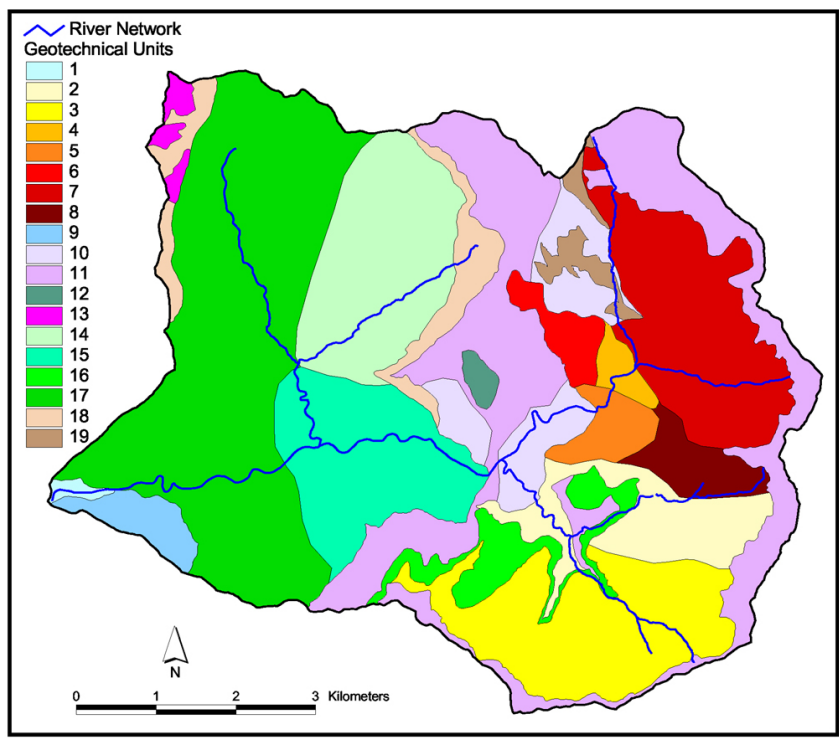

Fig. 13. Map of geotechnical units of River Vezza basin. (1) Talus and alluvial deposits; (2-8) units of Pseudomacigno formation; (9) stratified limestone; (10-11) units of dolomitic limestone; (12) saccharide limestone; (13) Grezzoni formation; (14-17) units of Verrucano formation; (18-19) porphiric schists.Geotechnical characteristics of terrains are summarised in Table 3.

can be considered quite reasonable when considering the geometry of the landslides that occurred on 19 June 1996. Most developed along slopes presenting a failure which occurred along a relatively shallow slip surfaces. The landslide bodies were somewhat small with respect to the flow length and slip surface generally parallel to the slope surface, triggered by heavy rainfall (Tarantino and Bosco, 2000).

The back-analysis has been implemented on selected representative test areas where geotechnical parameters and geometrical setting of landslides were available from direct field surveys, technical reports on slope reinforcement works and laboratory tests on soil samples. Geomechanical parameters 
Table 3. List of geotechnical units and associated physical and mechanical parameters detected for the geological formations of the Vezza basin (TR = Technical Report; FT = Field Test; LT = Laboratory Test)

\begin{tabular}{lcccc}
\hline Geological description &.$\gamma\left(\mathrm{kN} / \mathrm{m}^{3}\right)$ & $\mathrm{C}(\mathrm{kPa})$ &.$\phi\left(^{\circ}\right)$ & Type of information \\
\hline alluvial deposits & 19 & 4 & 30 & TR, FT \\
metasandstone "Pseudomacigno" (a) & 20 & 6 & 33 & LT, FT \\
metasandstone "Pseudomacigno" (b) & 20 & 8 & 30 & LT, FT \\
metasandstone "Pseudomacigno" (c) & 21 & 7 & 30 & LT, FT \\
metasandstone "Pseudomacigno" (d) & 21 & 8 & 34 & LT, FT \\
metasandstone "Pseudomacigno" (e) & 21 & 7 & 28 & LT, FT \\
metasandstone "Pseudomacigno" (f) & 19 & 6 & 30 & LT, FT \\
metasandstone "Pseudomacigno" (g) & 20 & 10 & 35 & LT, FT \\
stratified limestone & 25 & 13 & 43 & TR \\
dark grey dolomite (a) & 23 & 10 & 35 & TR \\
dark grey dolomite (b) & 24 & 10 & 37 & TR \\
saccharide limestone & 26 & 25 & 45 & TR \\
limestone "Grezzoni" & 26 & 25 & 35 & TR \\
phyllite "Verrucano" (a) & 21 & 10 & 28 & LT, FT \\
phyllite "Verrucano" (b) & 19 & 10 & 28 & LT, FT \\
phyllite "Verrucano" (c) & 19 & 10 & 28 & LT, FT \\
phyllite "Verrucano" (d) & 22 & 12 & 30 & LT, FT \\
porphyric schists (a) & 22 & 12 & 32 & TR, FT \\
porphyric schists (b) & 21 & 10728 & TR, FT & \\
\hline
\end{tabular}

have been finally summarised and spatialised. Each lithological formation is subdivided into homogeneous areas, obtaining 19 distinct lithotypes (Fig. 13). The geotechnical parameters associated with the vector map and the type of information is reported in Table 3 .

\section{Reference model}

The application of the stability model at basin scale, through a GIS, requires the acquisition of all input parameters. These constitute the expression of the safety factor (Eq. 1) as vector layers in order to spatialise the results derived from the computation of the equations of slope stability (Skempton and DeLory, 1957).

$$
F=\frac{c^{\prime}+\left(\gamma z-\gamma_{w} z_{w}\right) \cos ^{2} \beta \tan \varphi^{\prime}}{\gamma z \operatorname{sen} \beta \cos \beta}
$$

where:

$$
\begin{aligned}
F & =\text { safety factor } \\
c^{\prime} & =\text { effective cohesion }(\mathrm{kPa}) \\
\gamma & =\text { unit weight of soil }\left(\mathrm{kN} / \mathrm{m}^{3}\right) \\
\gamma_{w} & =\text { unit weight of water }\left(\mathrm{kN} / \mathrm{m}^{3}\right) \\
z & =\text { depth of superficial soil cover }(\mathrm{m}) \\
z_{w} & =\text { height of water table }(\mathrm{m}) \\
\beta & =\text { slope inclination }\left(^{\circ}\right) \\
\phi^{\prime} & =\text { effective friction angle }\left(^{\circ}\right)
\end{aligned}
$$

Among all parameters, the critical soil depth is complex to estimate, since the thickness of saturated soil cover (potentially unstable) depends mainly on the severity of meteorological events. The subsistence of a functional connection between geology and slope angle has been assumed by the adopted methodology used to derive a digital soil depth map of the whole study area. In addition, the possibility of developing a soil cover is strictly connected to morphology, climate and the mechanical properties of rocks. The hydrographic basin of Vezza (taking into account all the mentioned factors and its limited extension) can be considered as a geomorphologic and climatic unit that may result in a certain uniformed development of a superficial soil cover. In order to simplify the study, all geological formations of the Vezza basin have been grouped into three distinct classes, stressing, primarily, the geomechanical properties of superficial soil cover that are affected by debris flows: calcareous formations (limestone, dolomite, marbles), phyllites (Verrucano and porphiric schists) and metamorphic sandstone (Pseudomacigno).

Over 70 representative measurement spots, where soil cover depth was assessable, have been selected, interpreted and divided into in three different geological formations following this approach (Pseudomacigno, Verrucano and limestone formations). There was an assumed link between the thickness of the soil and the slope angle. In each site, the values of the soil depth were compared with the slope inclination and all data were plotted and interpolated (Fig. 14). 


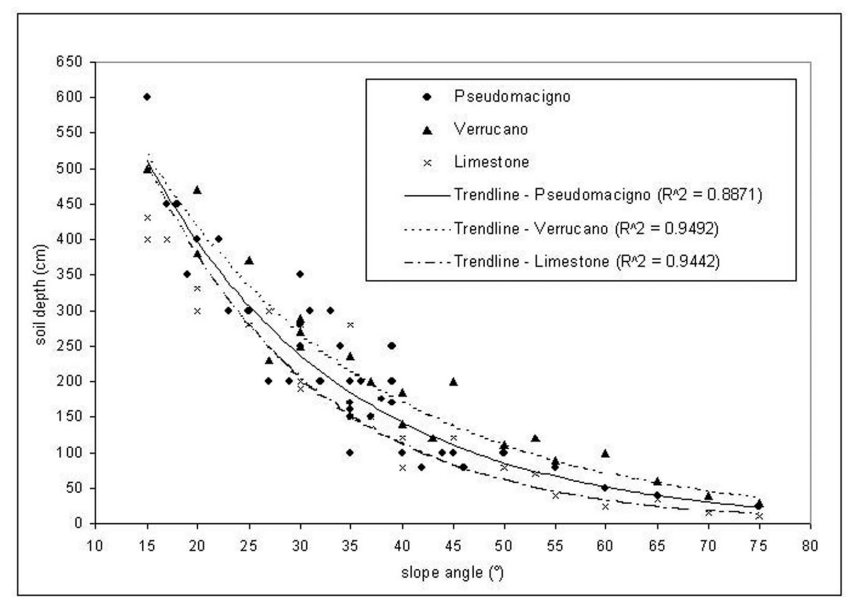

Fig. 14. Correlation between soil cover depth and slope angle of main geological formations affected by landslides triggered during the event in the River Vezza basin. Data have been calculated through interpolation of 70 field measurements.

This operation has allowed the detection of a positive correspondence between soil cover thickness and associated slope angles, with R2 variable from 0.88 and 0.94 . Therefore, three distinct functions have been found and spatialised throughout the area using a GIS that depicts a soil cover depth map (Fig. 15).

\section{Hydrological analysis}

In order to analyse the capability of superficial terrains prone to debris flows outcropping in the Vezza basin to generate critical pore pressures, it is necessary to adopt a simple hydrological model which can be used to study the relationship between rainfall amount (expressed as return time) and depth of soil cover. The application of temporal parameters such as critical rainfall with respect to return time (probability of occurrence) allows the transformation of susceptibility analysis into hazard assessment. The saturated critical depth for each class of terrain, which is derived from the application of a hydrological model, is adopted adopted in the safety factor calculation through the limit equilibrium method and with the infinite slope model.

It is generally recognised that precipitation that induces debris flows originates from a pore pressure. Seepage as well as ponding increases when very intense rainfall occurs (Campbell, 1975; Ellen, 1988; Fleming et al., 1989). Usually, the reference model assumes a vertical infiltration of rainfall within the slope and a consequent generation of pore pressure due to the increase of saturation over the contact soil-bedrock (Campbell, 1975). It is widely accepted that for slopes susceptible to superficial landslides, a critical soil depth of the saturation zone exists. After which the slope becomes unstable (Campbell, 1975). This critical soil depth depends on the slope angle, the shear strength of materials and

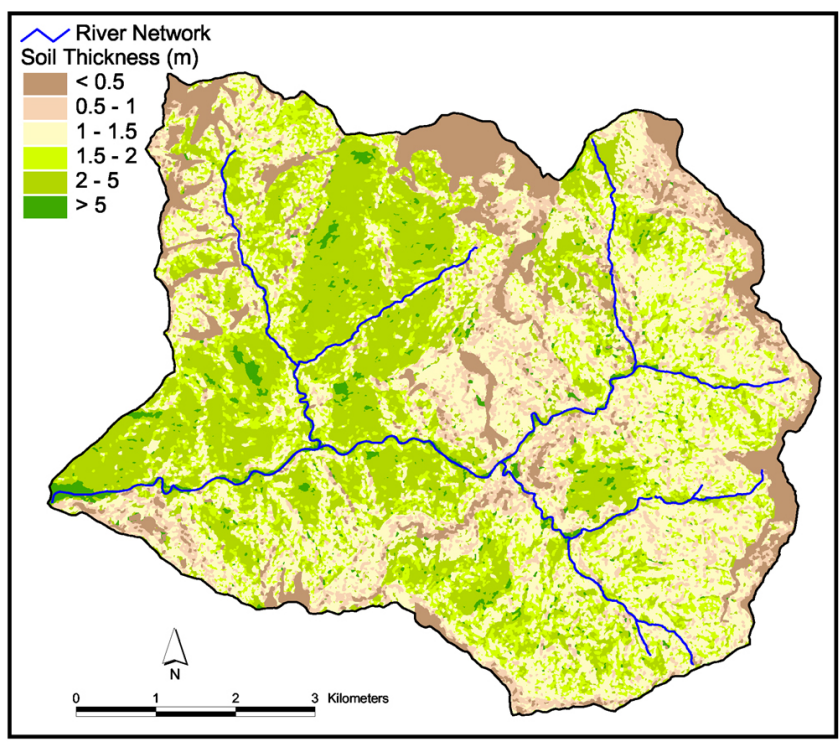

Fig. 15. Map of soil cover thickness distribution in the River Vezza basin.

the seepage geometry throughout the saturation zone. Taking into consideration the whole soil depth of the slope, the rainfall amount requested to saturate the slope can be simply expressed in the Eq. (2):

$z=H_{w} * n_{e f}$

where $z$ is the amount of retained rainfall $(\mathrm{mm}), H_{w}$ represents the vertical soil depth that presents a certain saturation degree before initial precipitation (m) and $n_{e f}$ is the effective porosity (\%). If the effective porosity $n_{e f}$ is expressed in terms of water content, $w$, or saturation degree, $S_{r}$, then it can be demonstrated that:

$n_{e f}=1-\frac{\gamma_{d}\left(\frac{1}{G}+w\right)}{\gamma_{w}}=1-\frac{\gamma_{d}\left[1+\left(\frac{G}{\gamma_{d}}-1\right) \cdot S_{r}\right]}{G \gamma_{w}}$

where $\gamma_{d}$ is the dry unit weight, $\gamma_{w}$ is the water unit weight and $G$ is the mineral grains unit weight of the soil that covers the slope.

\subsection{Green-Ampt analysis}

The time interval between the starting of precipitation and the generation of pore pressure at a certain depth can be estimated using the Green-Ampt analysis (Green and Ampt, 1911; Fuchu et al., 1998). Assuming an incipient ponding over the slope surface, the time $t_{d}$ necessary for the wet front to saturate the soil at a depth $D$ can be assessed as follows:

$t_{d}=\frac{\theta_{S}-\theta_{0}}{K_{s}}\left[D-h_{e} \ln \left(\frac{h_{e}+D}{h_{e}}\right)\right]$

where $\theta_{S}$ is the volumetric water content of the saturated soil, $\theta_{0}$ is the initial volumetric water content, $K_{s}$ the saturated 
Table 4. Parameters used in Green-Ampt analysis

\begin{tabular}{lccccc}
\hline Geological formations & $\gamma_{d}\left(\mathrm{kN} / \mathrm{m}^{3}\right)$ & $G\left(\mathrm{kN} / \mathrm{m}^{3}\right)$ & $S_{r}$ & $h_{e}(\mathrm{kPa})$ & $K_{s}(\mathrm{~m} / \mathrm{s})$ \\
\hline Pseudomacigno & 13.5 & 26.5 & $0.1-0.9$ & 10 & $2 \times 10^{-7}$ \\
Verrucano & 15.4 & 27.5 & $0.1-0.9$ & 10 & $7 \times 10^{-9}$ \\
Limestone & 20.0 & 27.5 & $0.1-0.9$ & 10 & $1 \times 10^{-6}$ \\
\hline
\end{tabular}

Table 5. Saturated soil thickness vs. distinct initial saturation degree $\left(S_{r}\right)$

\begin{tabular}{lcc}
\hline & Soil thickness $(\mathrm{m})$ & $S_{r}$ \\
\hline Pseudomacigno & $1.05-2.70$ & $0.1-0.6$ \\
Verrucano & $1.00-3.00$ & $0.1-0.7$ \\
Limestone & $1.90-2.90$ & $0.1-0.4$
\end{tabular}

hydraulic conductivity of the soil and $h_{e}$ the main effective pore pressure below the wet front.

The Eqs. (3) and (4) have been applied taking into account the parameters listed in Table 4 derived from laboratory tests $\left(\gamma_{d}, G\right.$ and $\left.K_{s}\right)$ and literature $\left(h_{e}\right)$ assigning a value according to average texture of soils (Pradel and Raad, 1993).

The Green-Ampt analysis has been implemented considering distinct pluviometric data with respect to the geographical distribution of terrains and rain gauge stations: $480 \mathrm{~mm}$ of precipitation (Pomezzana station) in Pseudomacigno and Limestone and $400 \mathrm{~mm}$ (Retignano station) in Verrucano, both located in the study area and representative of the meteorological condition of the catchment.

The difference of hydraulic conductivity during a rainstorm depends essentially on the nature of the debris. From results of Green-Ampt analysing, summarised in Tables 5 and 6 , the rainfall of 19 June 1996 was able to promote the triggering of debris flows that mobilised soil depths variable from 1 to $3 \mathrm{~m}$ by considering an initial saturation degree from 0.1 to 0.7 . Field analysis of Sr, undertaken in the study area under a similar climatic environment, suggests the assumption that the average saturation conditions of terrains vary from $30 \%$ to $50 \%$ (ENEA, 1998). Additionally, the same modelling permits the determination of the time between the starting of precipitation and the response of pore pressure along the interface soil-bedrock. From Table 6 it can be stressed that for the assumed saturation conditions, a time of approx. $7-8 \mathrm{~h}$ is required for mobilising soil cover depths $\leq 2 \mathrm{~m}$. This value is coherent with the time interval elapsed between the start of precipitation and the occurrence of the first debris flows, as testified by interviews with residents. Thickness $>2 \mathrm{~m}$, as observed in the test area, can be associated to a higher value of $S_{r}$ or, more likely, to a higher severity of precipitation in terms of intensity. Taking into account
Table 6. Thickness vs. ponding time

\begin{tabular}{cccc}
\hline Thickness (m) & $\begin{array}{c}\text { Pseudomacigno } \\
\text { Ponding } \\
\text { time (h) }\end{array}$ & $\begin{array}{c}\text { Verrucano } \\
\text { Ponding } \\
\text { time (h) }\end{array}$ & $\begin{array}{c}\text { Limestone } \\
\text { Ponding } \\
\text { time (h) }\end{array}$ \\
\hline 1.00 & 2.0 & 4.0 & 2.5 \\
1.50 & 4.3 & 9.0 & 5.4 \\
2.00 & 7.5 & 15.4 & 9.3 \\
2.50 & 11.4 & 23.4 & 14.2 \\
3.00 & 16.0 & 32.9 & 19.8 \\
\hline
\end{tabular}

that the recorded rainfall values are reasonably lower than the precipitation amount actually fallen on the slopes and considering the morphological effect of precipitation and the height of the rain gauge stations (325-597 $\mathrm{m}$ a.s.1.).

A further consideration can be made on hydrological susceptibility levels of geological formations. At basin scale, three different triggering hydrological thresholds can be discriminated (for the same levels of saturation degree and soil cover depth). Pseudomacigno and limestone formations present comparable ponding time values, while Verrucano has higher values. The minor occurrence of debris flows over areas where limestone formations outcrop, can be explained by different rheology of such materials that exhibit better strength conditions.

Finally, the different distribution of landsliding over metamorphic formations (higher for Pseudomacigno and lower for Verrucano) can be attributed to several factors. Besides dissimilar hydraulic response to rainfall, other factors include the morphological setting of phyllites in the basin, the lower precipitation amount fallen in the areas where this formation outcrops and lower slope angles. In addition, the presence of a larger clay fraction in the phyllites of Verrucano generates a higher saturated soil depth and, at the same time, for the same rainfall amount and thickness, a slower hydraulic conductivity. Conversely, in the Pseudomacigno formation, the saturation of phyllites occurs with a higher water content in a minor time. 
Table 7. Daily rainfall with return time of 10 years $(h=200 \mathrm{~mm})$

\begin{tabular}{lcc}
\hline Formations & $\begin{array}{c}\text { Depth of saturated } \\
\text { soil (m) }\end{array}$ & $\begin{array}{c}\text { Initial saturation } \\
\text { degree }(\%)\end{array}$ \\
\hline Pseudomacigno & 0.68 & 40 \\
Verrucano & 0.91 & 50 \\
Limestone & 1.05 & 30 \\
\hline
\end{tabular}

Table 8. Daily rainfall with return time of 50 years $(h=280 \mathrm{~mm})$

\begin{tabular}{lcc}
\hline Formations & $\begin{array}{c}\text { Depth of saturated } \\
\text { soil (m) }\end{array}$ & $\begin{array}{c}\text { Initial saturation } \\
\text { degree }(\%)\end{array}$ \\
\hline Pseudomacigno & 0.95 & 40 \\
Verrucano & 1.27 & 50 \\
Limestone & 1.47 & 30 \\
\hline
\end{tabular}

\section{Application of the model for rainfall with different return time}

A meteorological study done by the University of Nice (Carrega and Garcia, 1999) on development and singularity of the pluviometric event of 19 June 1996, has permitted, through the analysis of the available historical records of the area, the assessment of daily rainfall return time. This is a fundamental parameter for the evaluation of saturation levels of soil cover. From the analysis of rainfall values and return times computed for the Vezza basin and from the application of the hydrological model for distinct classes of geological formations, the following critical soil depths can be obtained. Referring to an assumed average value of $S_{r}$ of terrains (Tables $7,8,9,10$ ).

The application of the hydrological model to distinct soil covers outcropping in the Vezza basin has permitted the prediction of the spatial distribution of saturation conditions for different return times and the consequential expected daily rainfall amount (Fig. 16). Such a result is fundamental for implementing a predictive model of landsliding, based on distinct scenarios of rainfall and perched water table levels for each lithological domain.

\section{Hazard assessment}

Applying the Limit Equilibrium analysis (Eq. (1)) under variable conditions, a debris flow hazard map of the study area has been produced. The condition varied from a completely dry to a full saturated slope, taking into account the shear strength parameters of terrain, their critical soil depths and the adopted hydraulic modelling of transferring rainfall into pore pressure. The implementation of the safety factor function requires the vectorialisation of each thematic layer
Table 9. Daily rainfall with return time of 75 years $(h=330 \mathrm{~mm})$

\begin{tabular}{lcc}
\hline Formations & $\begin{array}{c}\text { Depth of saturated } \\
\text { soil (m) }\end{array}$ & $\begin{array}{c}\text { Initial saturation } \\
\text { degree }(\%)\end{array}$ \\
\hline Pseudomacigno & 1.12 & 40 \\
Verrucano & 1.50 & 50 \\
Limestone & 1.73 & 30 \\
\hline
\end{tabular}

Table 10. Daily rainfall with return time of 100 years $(h=400 \mathrm{~mm})$

\begin{tabular}{lcc}
\hline Formations & $\begin{array}{c}\text { Depth of saturated } \\
\text { soil (m) }\end{array}$ & $\begin{array}{c}\text { Initial saturation } \\
\text { degree }(\%)\end{array}$ \\
\hline Pseudomacigno & 1.36 & 40 \\
Verrucano & 1.82 & 50 \\
Limestone & 2.10 & 30 \\
\hline
\end{tabular}

(slope angle, soil depth and geomechanical features) and the intersection of the various themes in order to create elementary portions of territory (unique-condition units) (Carrara et al., 1995). This procedure allows the definition of polygons that, independently from their dimension, present characters of invariance in terms of slope angle, soil depth, bulk density, cohesion and internal friction angle. Namely, all the parameters included in the equation of infinite slope model.

A dynamic stability function has been implemented, through a GIS and using the results of the Green-Ampt modelling. This was based on distinct expected scenarios of precipitation, in terms of daily rainfall intensity and, consequently, of saturated soil thickness and the modification of the safety factor for each unit. From the implemented hydrological model, a critical saturated soil thickness, for each class of outcropping lithologies, has been calculated on the basis of 4 predicted pluviometric events with return times respectively of 10, 50, 75 and 100 years (Fig. 16).Then, the critical values of soil depths have been reported in the general expression of the safety factor for the infinite slope.

Finally, the calculation of the safety factor, from dry conditions and under expected return time of daily rainfall scenarios of 10 (Fig. 16A), 50 (Fig. 16B), 75 (Fig. 16C) and 100 years (Fig. 16D) has been performed. This operation has been implemented by varying the forces that reduce the shear strength of terrains (pore-pressures), keeping constant the resisting forces (geomechanical properties of soils), obtaining, as a consequence, a predictive model of slope stability for the study area.

The application of a distributed geotechnical modelling for the Vezza basin leads the identification in a 75 years return time rainfall $(280 \mathrm{~mm})$ of $90.7 \%$ of total landslide source areas (considering a safety factor value of 1.3 adopted by the Italian regulation for slope stability) with respect to $78.1 \%$ 


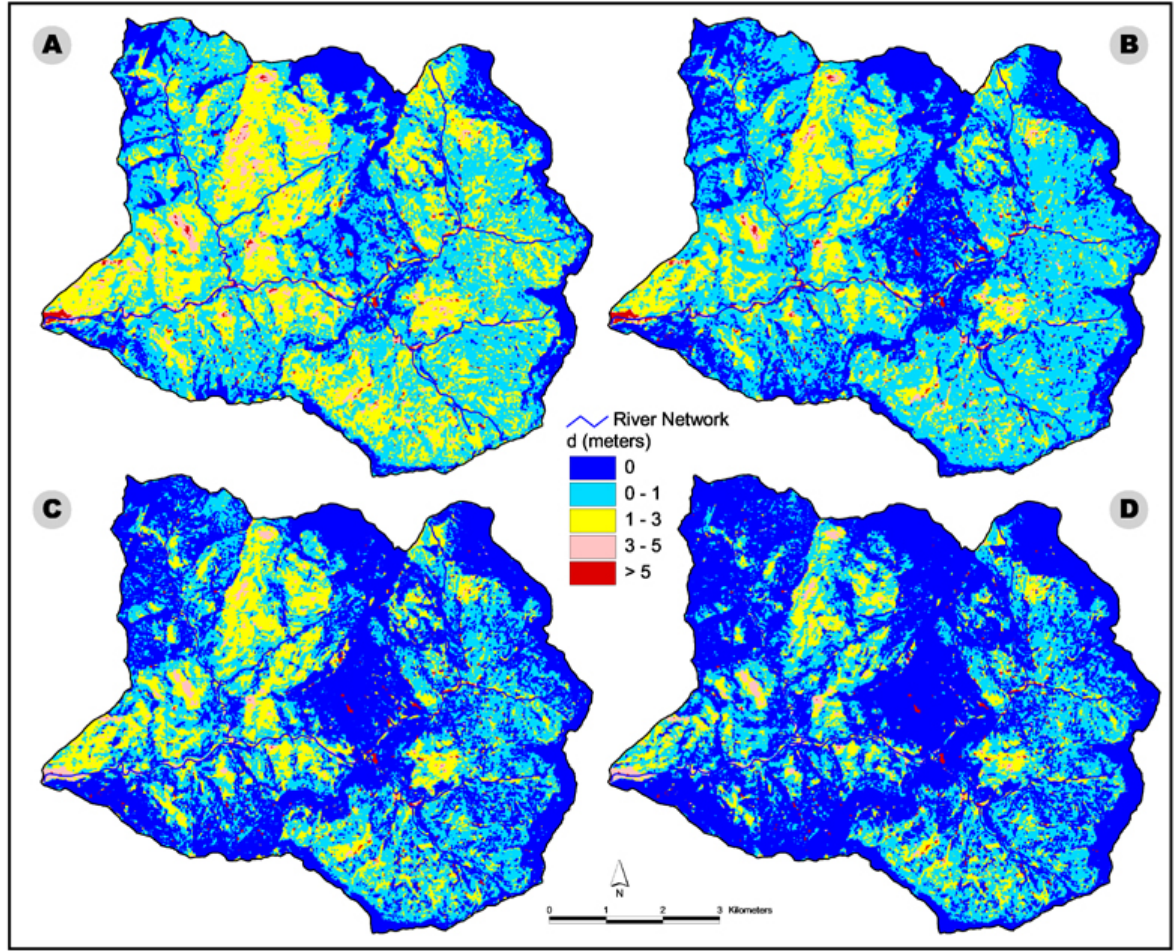

Fig. 16. Maps of heights of saturated soil cover. The values $d$ indicate the difference in meters between the ground level and the height of groundwater level in the River Vezza basin: $0=$ full saturation. (A): 10 years rainfall return time; $(\mathbf{B})$ : 50 years rainfall return time; (C): 75 years rainfall return time; $(\mathbf{D})$ : 100 years rainfall return time.

Table 11. Results from a deterministic analysis for rainfall return time of 75 years $(280 \mathrm{~mm})$

\begin{tabular}{lrr}
\hline & Surface $\mathrm{m}^{2}$ & \multicolumn{1}{c}{$\%$} \\
\hline Total area of polygons & 51636403 & 100.0 \\
Area of polygons with $\mathrm{SF} \leq 1$ & 22384294 & 43.3 \\
Area of polygons with $\mathrm{SF} \leq 1.3$ & 40335155 & 78.1 \\
Total of landslide source area & 240878 & 100.0 \\
Area of failures with SF $\leq 1$ & 162893 & 67.6 \\
Area of failures with SF $\leq 1.3$ & 218387 & 90.7 \\
\hline
\end{tabular}

of unstable area calculated for the Vezza basin. Analogously, for a $\mathrm{SF}=1$, the model identifies $67.6 \%$ of debris-flow source areas with respect to 43.4 of potential instability for the whole basin. A resume of results is shown in Table 11.

Following numerical simulations whose results have been outlined, for each iteration, through a G.I.S., the following scenarios have been analysed (Fig. 17).

(a) For a return time of 10 years, corresponding to $200 \mathrm{~mm}$ of rainfall (Fig. 17A), the most hazardous areas seem to match with those where there is a formation of Pseudomacigno outcrops. In particular, the villages of Pruno, Volegno, Cardoso and the sub-basin of Capriola torrent. Other minor instability areas involve the formation of Verrucano near the village of Stazzema. This situation is in accordance with the event of 19 June 1996 where the above areas recorded the highest landslide density per $\mathrm{km}^{2}$ in the whole study area.

(b) A rainfall event with an estimated return time of between 50 and 75 years, corresponding to $280-330 \mathrm{~mm}$ of precipitation (Fig. 17B and 17C) should result in large instabilities of Pseudomacigno formation. Most of Verrucano and, in particular, the villages of Ruosina, Levigliani and Vallinventre are involved.

c) For a cumulated rainfall of $400 \mathrm{~mm}$, with return time of 100 years (Fig. 17D), corresponding to the peaks of the 19 June 1996 event, the simulated scenario seems to involve potential unstable areas even larger than those actually mobilised.

\section{Results and conclusions}

The analysis of landslides occurring in the River Vezza basin on 19 June 1996 and the application of a physically-based approach using GIS for ascertaining landslide hazard in the area, lead to the following results:

i. superficial slide-debris-flows, with failure depth generally $<3 \mathrm{~m}$, developed during the rainstorm of 19 June 1996, resulted in the combination of severe meteorological conditions with the presence of soil cover over slopes;

ii. analysis of the hydrological response of hillslopes indicates that failures were caused by the development of 


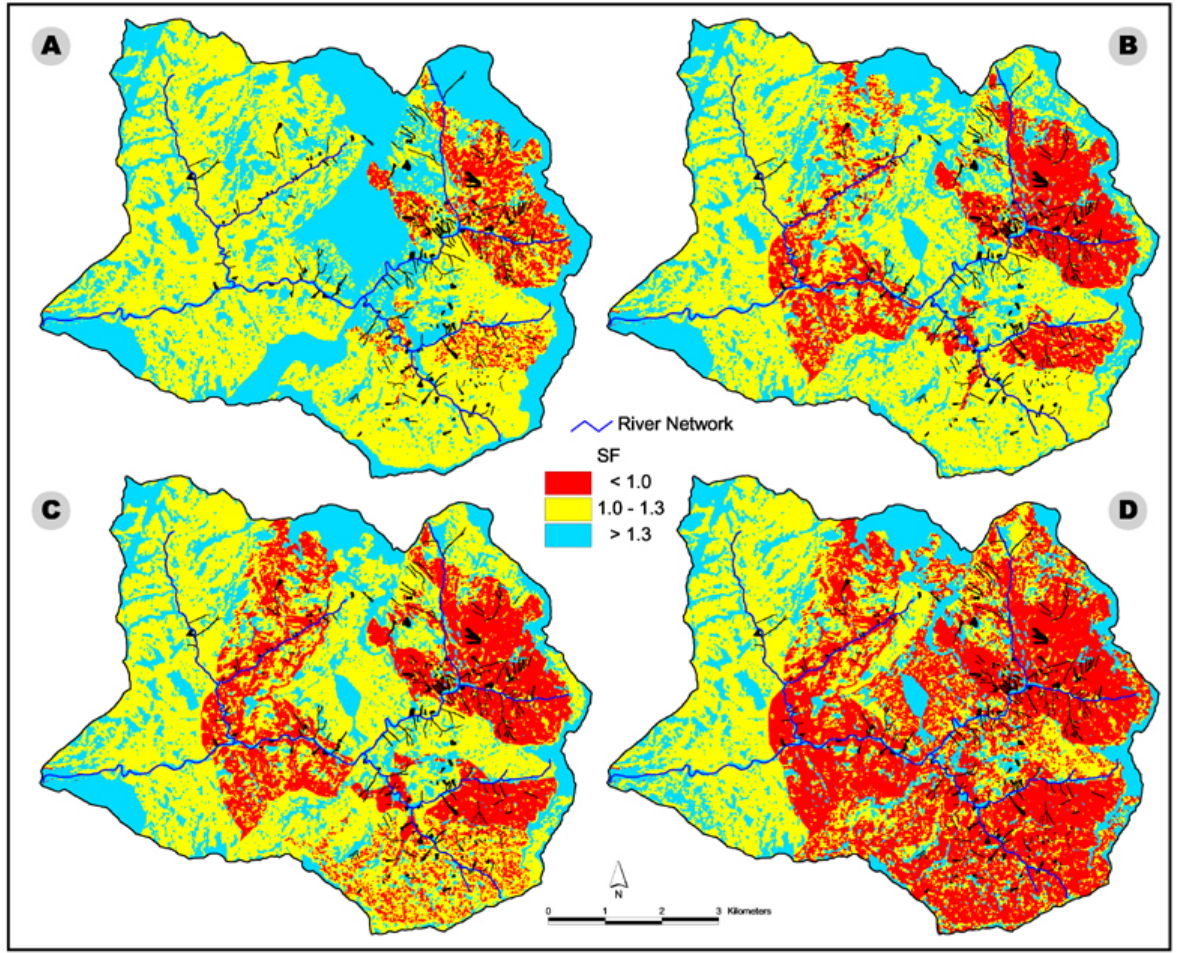

Fig. 17. Maps of safety factors (SF) distribution in the River Vezza basin calculated for the following estimated rainfall return time: (A) 10 years; (B) 50 years; (C) 75 years; (D) 100 years. Black areas show landslides of 19 June 1996.

a perched water table in the soil cover due to infiltration; results from the application of Green-Ampt analysis seems to match with field observations on landslide triggering initiation;

iii. occurrence of landslides is strictly dependent on some predisposing factors such as: presence of metasedimentary rocks that promote the development of superficial soil cover; high slope gradient and shape; the progressive degradation of forests due to lack of preservation;

iv. application of a deterministic distributed model has provided a scenario of potential slope instability with respect to 4 expected return time daily precipitation (10, $50,75,100$ years). The 75 years return time precipitation may represent the critical threshold for the basin of River Vezza (almost $80 \%$ of predicted landslides vs. actual landslides);

v. predicted scenarios of instability seem to fit with observed debris-flows just after the disaster. Considering a comparison made between expected unstable areas and debris-flows source areas triggered by the 19 June 1996 event; in addition, the modelling attributes the highest susceptibility for debris flow prone areas to Pseudomacigno and Verrucano respectively. Although a certain over-estimation of potential unstable areas is likely to attribute to a conservative assessment of strength parameters of terrain, as well as to the contribution of other factors (i.e. strength of root system, local slope shape conditions); vi. this approach can represent an effective tool for the assessment of debris-flow prone areas where the homogeneity of geological and morphological predisposing factors promotes a large diffusion of instability processes under well defined rainfall triggering values;

vii. under the above conditions, a hazard assessment by a deterministic approach can be done for large areas, starting from limited but representative data, through simplified modelling using a GIS.

Acknowledgements. This study is part of the EU project TEMRAPThe European Multi-hazard Risk Assessment Project, Contract N ENV 4 - CT97 0589, 5th Framework Program.

Authors wish to thank "Comunità Montana Alta Versilia" and the Municipalities of Stazzema and Seravezza for logistic and technical support for the investigation. Authors are also grateful to Vladimiro Verrubbi (ENEA, Rome) for geological and geomorphological interpretation and Cinzia Crovato (ENEA, Rome) for diffrattometry analysis and data elaboration. A special gratitude to Amanda Dawes for manuscript revision.

\section{References}

Aleotti, P. and Chowdhury, R.: Landslide hazard assessment: summary review and new perspectives, Bulletin of Engineering Geology and the Environment, 58, 21-44, 1999.

Burlando, P. and Rosso, R.: Caratterizzazione idrologica e prevedibilità statistica del nubifragio, in: 19 giugno 1996: alluvione in Versilía e Garfagnana, edited by Rosso, R. and Serva, L., ANPAARPAT, Firenze, (in Italian), 57-84, 1998. 
Campbell, R. H.: Soil Slip, Debris Flow, and Rainstorms in the Santa Monica Mountain and Vicinity, Southern California, U.S. Geol. Survey Prof. Paper 851, 51, 1975.

Carrara, A., D'Elia, B., and Semenza E.: Classificazione e nomenclatura dei fenomeni franosi, Geologia Applicata ed idrogeologia, Bari, (in Italian), 20, 2, 223-243, 1987

Carrara, A., Cardinali, M., Guzzetti, F., and Reichenbach, P.: GIS technology in mapping landslide hazard, in: Geographical Information Systems in Assessing Natural Hazard, edited by Carrara, A. and Guzzetti, F., Kluwer Academic Publisher, Dordrecht, The Netherlands, 135-175, 1995.

Carrega, P. and Garcia, E.: Heavy rainfall analysis, TEMRAP: The European Multi-Hazard Risk Assessment Project, Contract N ENV 4 CT97 0589, Intermediate Report, Université de NiceSophia Antipolis (UNSA), 48, 1999.

Codebò, L., Delmonaco, G., Margottini, C., Puglisi, C., and Serafini, S.: Landslide susceptibility in the Cardoso slope (Versilia, Italy): consequences of the flash flood of 19 June 1996, in: Landslides in Research, Theory and Practice, edited by Bromhead, E., Dixon, N. and Ibsen, M., Telford, London, 293-298, 2000.

Corominas, J., Remondo, J., Farias, P., Estevao, M., Zézere, J., Díaz de Terán, J., Dikau, R., Schrott, L., Moya, J., and Gonzalez, A.: Debris flow, in: Landslide Recognition, Identification, Movement and Causes, edited by Dikau, R., Brunsden, D., Schrott, L. and Ibsen, M., Wiley, 161-180, 1996.

Crosta, G., Guzzetti, F., and Marchetti, M.: Morphological classification of debris-flow processes in South-Central Alps (Italy), Proc. 6th Int. IAEG Congr. Balkema, Rotterdam, 1565-1572, 1990.

Cruden, D. M. and Varnes, D. J.: Landslide types and processes, in: Landslides, Investigation and Mitigation, Transportation Research Board, edited by Turner, A. K. and Schuster, R. L., Special report 247, Washington D. C., 36-75, 1996.

Dietrich, W. E. and Sitar, N.: Geoscience and geotechnical engineering aspects of debris-flow hazard assessment, Proc. First International Workshop on Debris-Flow Hazards Mitigation: Mechanics, Prediction and Assessment, ASCE, S. Francisco, August 7-9, 656-675, 1997.

Dietrich, E. W., Reiss, R., Hsu, M. L., and Montgomery, D. R.: A process-based model for colluvial soil depth and shallow landsliding using digital elevation data. Hydrological Process, 9, 383400, 1995 .

ENEA: Valutazione della stabilità geomorfologica del versante di Orzale (Stazzema - Lucca), Technical Report, Rome, (in Italian), 50, 1998.

Ellen, S. D.: Description and mechanics of soil slip/debris flows in the storm, in: Landslide, floods and marine effect of the storm of 3-5 January 1982, in San Francisco Bay Region, California. U.S, edited by Ellen, S. D., Wieczoreck, G. F., Geological Survey Professional Paper 1434, US Geological Survey, Washington, DC, 63-112, 1988.

Fleming, R. W., Ellen, S. D., and Algus, M. A.: Trasformation of dilative and contractive landslide debris into debris flow - an example from Marin County, California, Engineering Geology 27, 201-223, 1989.

Fuchu, D., Lee, C. F., and Sijimg, W.: Analysis of rainstorminduced slide-debris flows on natural terrain of Lantau Island,
Hong Kong, Engineering Geology, 51, 279-290, 1998.

Green, W. H. and Ampt, G. A.: Studies on soil physics, 1, The flow of air and water trough soil, J. Agric. Sci.,4, 1-24, 1911.

Guzzetti, F., Carrara, A., Cardinali, M., and Reichenbach, P.: Landslide hazard evaluation: a review of current techniques and their application in a multi-scale study, Central Italy, Geomorphology, 31, 181-216, 1999

Hutchinson, J. N.: Keynote paper: Landslide hazard assessment, in: Landslides, edited by Bell, D. H., Balkema, Rotterdam, 18051841, 1995.

Montgomery, D. R. and Dietrich, W. E.: A phisically based model for the topographic control on shallow landsliding, Water Resour. Res., 30(4), 1153-1171, 1994.

Paolini, S. and Martini, G.: Historical research and catalogue. TEMRAP: The European Multi-Hazard Risk Assessment Project, Contract N ENV 4 - CT97 0589, Intermediate Report, ENEA CR Casaccia, Rome, 60, 2000.

Pierson, T. C. and Costa, J. E.: A rheologic classification of subaerial sediment-water flows, in: Debris flows/avalanches: process, recognition and mitigation, edited by Costa, J. E. and Wieczorek, G. F., Geol. Soc. Am., Rev. Eng. Geol., 7, 1-12, 1987.

Pradel, D. and Raad, G.: Effect of permeability on surficial stability of homogenous slopes, Journal of Geotechnical Engineering ASCE 119 (2), 315-332, 1993.

Rapetti, C. and Rapetti, F.: L'evento pluviometrico eccezionale del 19 giugno 1996 in Alta Versilia (Toscana) nel quadro delle precipitazioni delle Alpi Apuane, Atti della Società Toscana di Scienze Naturali, Memorie, Serie A, Vol. CIII, (in Italian), 143159, 1996.

Skempton, A. W. and DeLory, F. A.: Stability of natural slopes in London Clay. Proc. 4th Int. Conf. Soil Mech., London, 2, 378381, 1957.

Tarantino, A. and Bosco, G.: Role of soil suction in understanding the triggering mechanism of flow slides associated with rainfall, In: Wieczorek, G. F. and Naeser, N. D. (eds.), DebrisFlow Hazard Mitigation: Mechanics, Prediction and Assessment, Balkema, Rotterdam, Brookfield, 81-88, 2000.

Terlien, M. T. J., van Westen, C. J., and van Asch, Th. W. J.: Deterministic modelling in GIS-based landslide hazard assessment, in: Geographical Information Systems in Assessing Natural Hazards, edited by Carrara, A., Guzzetti, F., Kluwer Academic Publisher, Dordrecht, The Netherlands, 57-77, 1995.

Van Westen, C. J.: Application of Geographical Information Systems to landslide hazard zonation, ITC Publication No 15, ITC, Enschede, The Netherlands, 245, 1993.

Van Westen, C. J.: G.I.S. in landslide hazard zonation: a review with examples from the Colombian Andes, edited by Price, M. F. and Heywood, D. I., Taylor and Francis, London, 135-165, 1994.

Wieczorek, G. F.: Effect of rainfall intensity and duration on debris flow in central Santa Cruz Mountains, California, in: Debris flows/avalanches: process, recognition and mitigation, edited by Costa, J. E. and Wieczorek, G. F., Geol. Soc. Am., Eng. Geol., 7, 93-104, 1987.

Wieczorek, G. F.: Landslide triggering mechanism, in: Landslides, Investigation and Mitigation, edited by Turner, A. K. and Schuster, R. L., Transportation Research Board, Special report 247, Washington D. C., 76-90, 1996. 